\title{
Geology and Assessment of Undiscovered Oil and Gas Resources of the East Siberian Sea Basin Province, 2008
}

Chapter $\mathrm{Y}$ of

The 2008 Circum-Arctic Resource Appraisal

Professional Paper 1824

U.S. Department of the Interior

U.S. Geological Survey 
COVER Eocene strata along the north side of Van Keulenfjorden, Svalbard, include basinfloor fan, marine slope, and deltaic to fluvial depositional facies. The age and facies of these strata are similar to Tertiary strata beneath the continental shelves of Arctic Eurasia, thus providing an analog for evaluating elements of those petroleum systems. Relief from sea level to top of upper bluff is approximately 1,500 feet. Photograph by David Houseknecht. 


\section{Geology and Assessment of Undiscovered Oil and Gas Resources of the East Siberian Sea Basin Province, 2008}

By Kenneth J. Bird, David W. Houseknecht, and Janet K. Pitman

Chapter $Y$ of

The $\mathbf{2 0 0 8}$ Circum-Arctic Resource Appraisal

Edited by T.E. Moore and D.L. Gautier

Professional Paper 1824 


\title{
U.S. Department of the Interior \\ RYAN K. ZINKE, Secretary
}

\author{
U.S. Geological Survey \\ James F. Reilly II, Director
}

U.S. Geological Survey, Reston, Virginia: 2018

For more information on the USGS - the Federal source for science about the Earth, its natural and living resources, natural hazards, and the environment-visit https://www.usgs.gov or call 1-888-ASK-USGS.

For an overview of USGS information products, including maps, imagery, and publications,

visit https://store.usgs.gov.

Any use of trade, firm, or product names is for descriptive purposes only and does not imply endorsement by the U.S. Government.

Although this information product, for the most part, is in the public domain, it also may contain copyrighted materials as noted in the text. Permission to reproduce copyrighted items must be secured from the copyright owner.

Suggested citation:

Bird, K.J., Houseknecht, D.W., and Pitman, J.K., 2018, Geology and assessment of undiscovered oil and gas resources of the East Siberian Sea Basin Province, 2008, chap. Y of Moore, T.E., and Gautier, D.L., eds., The 2008 Circum-Arctic Resource Appraisal: U.S. Geological Survey Professional Paper 1824, 11 p., https://doi.org/10.3133/pp1824Y.

ISSN 2330-7102 (online) 


\section{The 2008 Circum-Arctic Resource Appraisal}

\section{Chapter}

A. Introduction to the 2008 Circum-Arctic Resource Appraisal (CARA) Professional Paper By Donald L. Gautier and Thomas E. Moore

B. Methodology for Assessment of Undiscovered Oil and Gas Resources for the 2008 Circum-Arctic Resource Appraisal

By Ronald R. Charpentier

C. Geology and Assessment of Undiscovered Oil and Gas Resources of the Chukchi Borderland Province, 2008

By Kenneth J. Bird and David W. Houseknecht

D. Geology and Undiscovered Oil and Gas Resources of the Hope Basin Province, 2008

By Kenneth J. Bird, David W. Houseknecht, and Janet K. Pitman

E. Geology and Assessment of Undiscovered Oil and Gas Resources of the Arctic Alaska Petroleum Province, 2008

By David W. Houseknecht, Kenneth J. Bird, and Christopher P. Garrity

F. Geology and Assessment of Undiscovered Oil and Gas Resources of the Central Alaska Province, 2008

By Kenneth J. Bird and Richard G. Stanley

G. Geology and Assessment of Undiscovered Oil and Gas Resources of the Northwest Canada Interior Basins Province, Arctic Canada, 2008

By Marilyn E. Tennyson and Janet K. Pitman

H. Geology and Assessment of Undiscovered Oil and Gas Resources of the Franklinian Shelf Province, Arctic Canada and North Greenland, 2008

By Marilyn E. Tennyson and Janet K. Pitman

I. Geology and Assessment of Undiscovered Oil and Gas Resources of the Sverdrup Basin Province, Arctic Canada, 2008

By Marilyn E. Tennyson and Janet K. Pitman

J. Geology and Assessment of Undiscovered Oil and Gas Resources of the West Greenland-East Canada Province, 2008

By Christopher J. Schenk

K. Geology and Assessment of Undiscovered Oil and Gas Resources of the East Greenland Rift Basins Province, 2008

By Donald L. Gautier 
L. Geology and Assessment of Undiscovered Oil and Gas Resources of the Jan Mayen Microcontinent Province, 2008

By Thomas E. Moore and Janet K. Pitman

M. Geology and Assessment of Undiscovered Oil and Gas Resources of the Mezen' Basin Province, 2008

By Timothy R. Klett and Janet K. Pitman

N. Geology and Assessment of Undiscovered Oil and Gas Resources of the Timan-Pechora Basin Province, Russia, 2008

By Christopher J. Schenk

0. Geology and Assessment of Undiscovered Oil and Gas Resources of the East Barents Basins Province and the Novaya Zemlya Basins and Admiralty Arch Province, 2008

By Timothy R. Klett

P. Geology and Assessment of Undiscovered Oil and Gas Resources of the North Kara Basins and Platforms Province, 2008

By Timothy R. Klett and J.K. Pitman

0. Geology and Assessment of Undiscovered Oil and Gas Resources of the Northern West Siberian Mesozoic Composite Total Petroleum System of the West Siberian Basin Province, Russia, 2008

By Christopher J. Schenk

R. Geology and Assessment of Undiscovered Oil and Gas Resources of the YeniseyKhatanga Basin Province, 2008

By Timothy R. Klett and Janet K. Pitman

S. Geology and Assessment of Undiscovered Oil and Gas Resources of the Northwest Laptev Sea Shelf Province, 2008

By Timothy R. Klett and Janet K. Pitman

T. Geology and Assessment of Undiscovered Oil and Gas Resources of the Lena-Anabar Basin Province, 2008

By Timothy R. Klett and Janet K. Pitman

U. Geology and Assessment of Undiscovered Oil and Gas Resources of the Tunguska Basin Province, 2008

By Craig J. Wandrey and Timothy R. Klett

V. Geology and Assessment of Undiscovered Oil and Gas Resources of the Lena-Vilyui Basin Province, 2008

By Timothy R. Klett and Janet K. Pitman

W. Geology and Assessment of Undiscovered Oil and Gas Resources of the Laptev Sea Shelf Province, 2008

By Timothy R. Klett and Janet K. Pitman 
X. Geology and Assessment of Undiscovered Oil and Gas Resources of the Zyryanka Basin Province, 2008

By Timothy R. Klett and Janet K. Pitman

Y. Geology and Assessment of Undiscovered Oil and Gas Resources of the East Siberian Sea Basin Province, 2008

By Kenneth J. Bird, David W. Houseknecht, and Janet K. Pitman

Z. Geology and Assessment of Undiscovered Oil and Gas Resources of the Vilkitskii Basin Province, 2008

By Kenneth J. Bird, David W. Houseknecht, and Janet K. Pitman

AA. Geology and Assessment of Undiscovered Oil and Gas Resources of the Long Strait Basin Province, 2008

By Kenneth J. Bird, David W. Houseknecht, and Janet K. Pitman

BB. Geology and Assessment of Undiscovered Oil and Gas Resources of the Amerasia Basin Petroleum Province, 2008

By David W. Houseknecht, Kenneth J. Bird, and Christopher P. Garrity

CC. Geology and Assessment of Undiscovered Oil and Gas Resources of the LomonosovMakarov Province, Central Arctic Ocean, 2008

By Thomas E. Moore, Kenneth J. Bird, and Janet K. Pitman

DD. Geology and Assessment of Undiscovered Oil and Gas Resources of the Eurasia Basin Province, Eastern Arctic Ocean, 2008

By Thomas E. Moore and Janet K. Pitman 


\section{Contents}

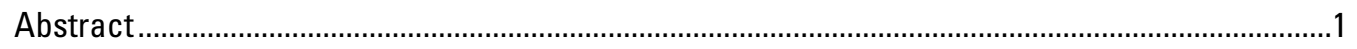

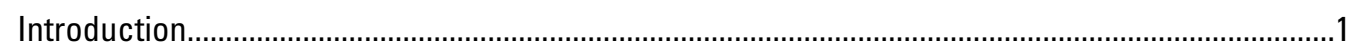

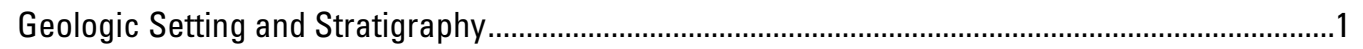

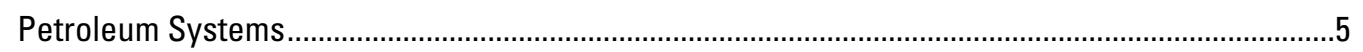

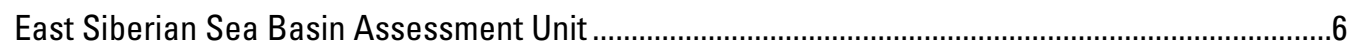

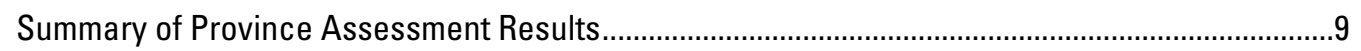

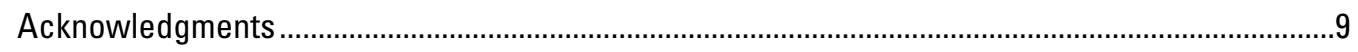

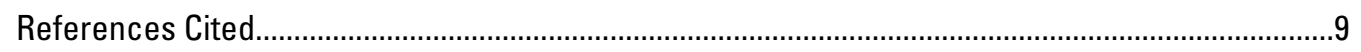

\section{Appendix}

[Available for download at https://doi.org/10.3133/pp1824Y]

1. Input Data for the East Siberian Sea Basin Assessment Unit

\section{Figures}

1. Map showing the East Siberian Sea Basin and other sedimentary basins of the East Siberian and Chukchi Seas that lie within and adjacent to the Brooks Range-Chukotka orogenic belt.

2. Selected details of the East Siberian Sea. $A$, Map of East Siberian Sea Basin, showing depth to acoustic basement and locations of selected seismic lines and pseudowell used in burial-history analysis. $B$, Area of figure $2 A$, superimposed on a free-air-gravity-anomaly map.

3. Schematic stratigraphic succession that likely extends into the East Siberian Sea Basin, interpreted from outcrops and shallow drill holes on the New Siberian Islands..

4. Cross section drawn from analysis of seismic line LARGE 89001, showing depositional sequences and provisional ages.

5. Cross section of deep synclinal sag and associated listric normal faults in the East Siberian Sea Basin drawn from analysis of seismic profile BGR94-12.

6. Burial-history analysis of pseudowell located in a deep synclinal sag of the East Siberian Sea Basin traversed by the seismic-reflection profile in figure 5.

\section{Tables}

1. Assessment results for the East Siberian Sea Basin Province (conventional undiscovered resources). 


\title{
Chapter Y
}

\section{Geology and Assessment of Undiscovered Oil and Gas Resources of the East Siberian Sea Basin Province, 2008}

\author{
By Kenneth J. Bird, David W. Houseknecht, and Janet K. Pitman
}

\section{Abstract}

The East Siberian Sea Basin, which lies beneath the continental shelf east of the New Siberian Islands, is one of the better-known basins in a series of postorogenic (successor) basins in the East Siberian-Chukchi Sea region because of a reconnaissance network of seismic-reflection profiles and outcrops on nearby islands. In spite of the seismic coverage, the basin's petroleum potential is poorly known. It is considered a separate petroleum province for the purposes of the Circum-Arctic Resource Appraisal. The probability that the East Siberian Sea Basin contains at least one undiscovered accumulation $>50$ million barrels of oil equivalent (MMBOE) is considered to be $\sim 22$ percent. A single assessment unit was defined and studied, resulting in mean estimates of technically recoverable conventional undiscovered resources of $\sim 20$ million barrels of oil (MMBO) and 580 billion cubic feet of gas (BCFG), nonassociated.

\section{Introduction}

The East Siberian Sea Basin, the westernmost of six sedimentary basins situated on the continental shelf of the East Siberian and western Chukchi Seas (fig. 1), lies just east of the New Siberian Islands, west of the Vilkitskii Basin, and north of the Chaun Basin. The East Siberian Sea Basin has an elongate northwesterly trend, with dimensions of $\sim 600$ by $\sim 250 \mathrm{~km}$, and covers an area of $120,000 \mathrm{~km}^{2}$. The basin lies north of the Arctic Circle entirely offshore in $25-$ to $50-\mathrm{m}$ water depths (fig. 1). For the purposes of this assessment, the East Siberian Sea Basin is designated as both a separate province and an assessment unit (AU).

\section{Geologic Setting and Stratigraphy}

The East Siberian Sea Basin is mostly a successor or intermontane basin that formed across the Brooks RangeChukotka orogenic belt of the Arctic Alaska-Chukotka microplate. The orogenic belt is northward vergent, extending from the South Anyui suture on the south to the Herald
Arch-Lisburne Hills-Brooks Range thrust front on the north (fig. 1). The South Anyui suture, distinguished by discontinuous occurrences of ophiolites, marks the closure of the South Anyui ocean basin during the latest Jurassic and Early Cretaceous (Neocomian). The thrust front of the orogenic belt, however, may be as young as early Paleogene ( $\sim 60 \mathrm{Ma}$ ) if timing is similar to that on the Alaskan North Slope. A small part (10-15 percent) of the East Siberian Sea Basin lies north of the thrust front and may compose a foreland-basin sedimentary succession, with ages, depositional environments, and lithologies similar to those in the North Slope Foreland Basin to the east. The De Long Massif (fig. 2), which borders this foreland-basin succession on the north, represents the autochthon of the orogenic belt. This autochthon is characterized by positive free-air gravity anomalies (fig. $2 B)$ and $<1 \mathrm{~km}$ of mid-Cretaceous and younger volcanic and sedimentary cover (fig. 3) that unconformably overlies deformed Paleozoic strata and igneous rocks. A seismic profile (fig. 4) shows northward onlap of the foreland-basin strata, as well as southward-fanning reflectors within the autochthonous (pre-foreland basin) section that is typically assigned to the acoustic basement.

Although the origin of the East Siberian Sea Basin is uncertain, the observed structural and stratigraphic features revealed by seismic profiles generally are compatible with strike-slip faulting, which has been proposed in numerous scenarios as affecting the entire shelf of the East Siberian Sea after the cessation of Arctic Alaska-Chukotka microplate orogenesis. The orientation and number of suggested strikeslip faults, however, vary widely; a regional system of northwest- and northeast-trending faults was proposed on the basis of alignments or apparent offsets of potential-field anomalies (for example, Mazarovich and Sokolov, 2003; Filatova and Khain, 2007), whereas other studies specific to the East Siberian Sea Basin (for example, Franke and others, 2004) proposed east-trending faults perpendicular to structural sags and pull-apart basins. According to most workers, strike-slip faulting was driven by the Cenozoic opening of the Eurasia Basin.

Details of the East Siberian Sea Basin are summarized here on a structure-contour map (fig. 2), a stratigraphic column showing the possible lithologic succession and ages (fig. 3), and a cross section based on a seismic profile 


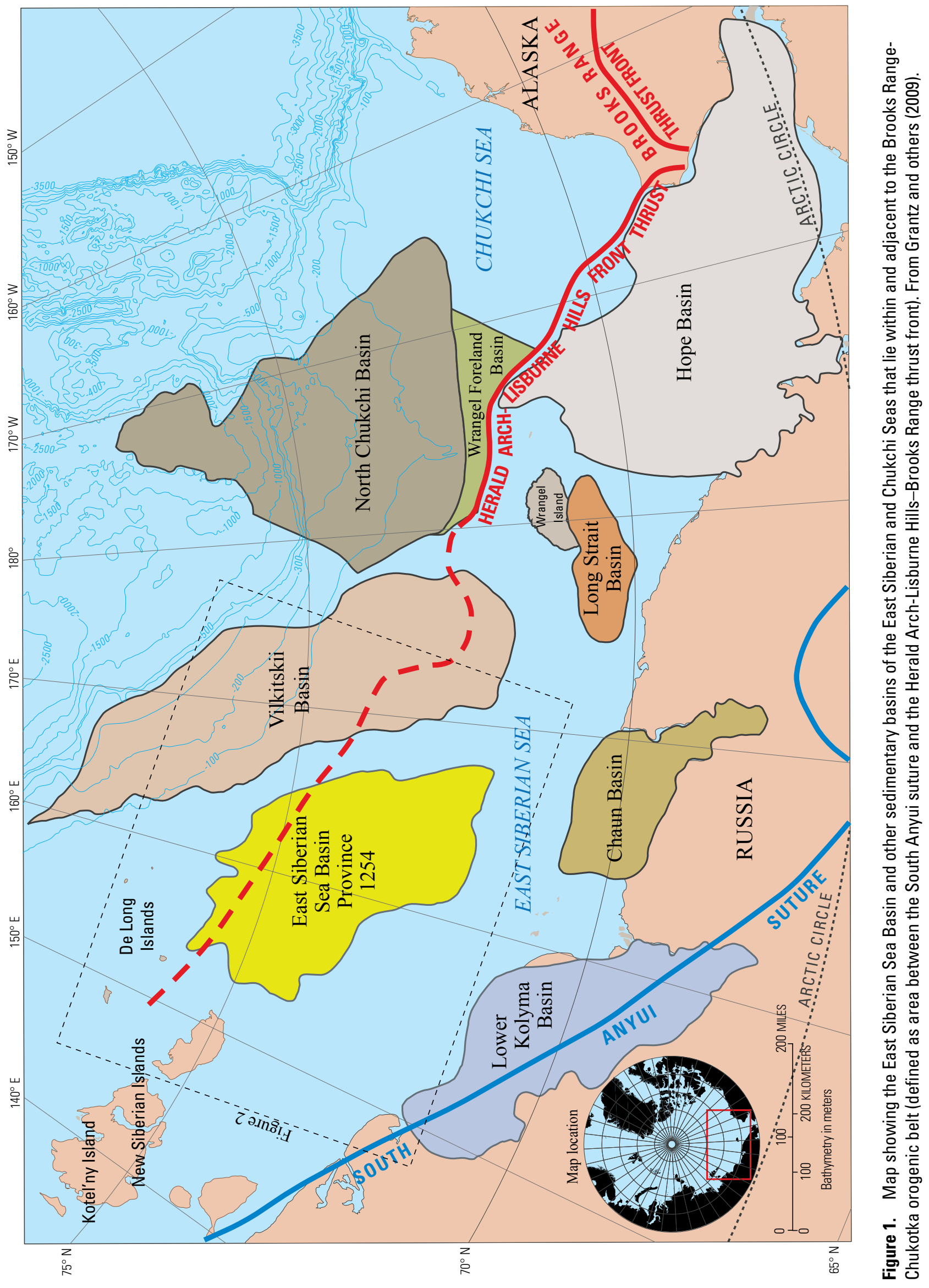



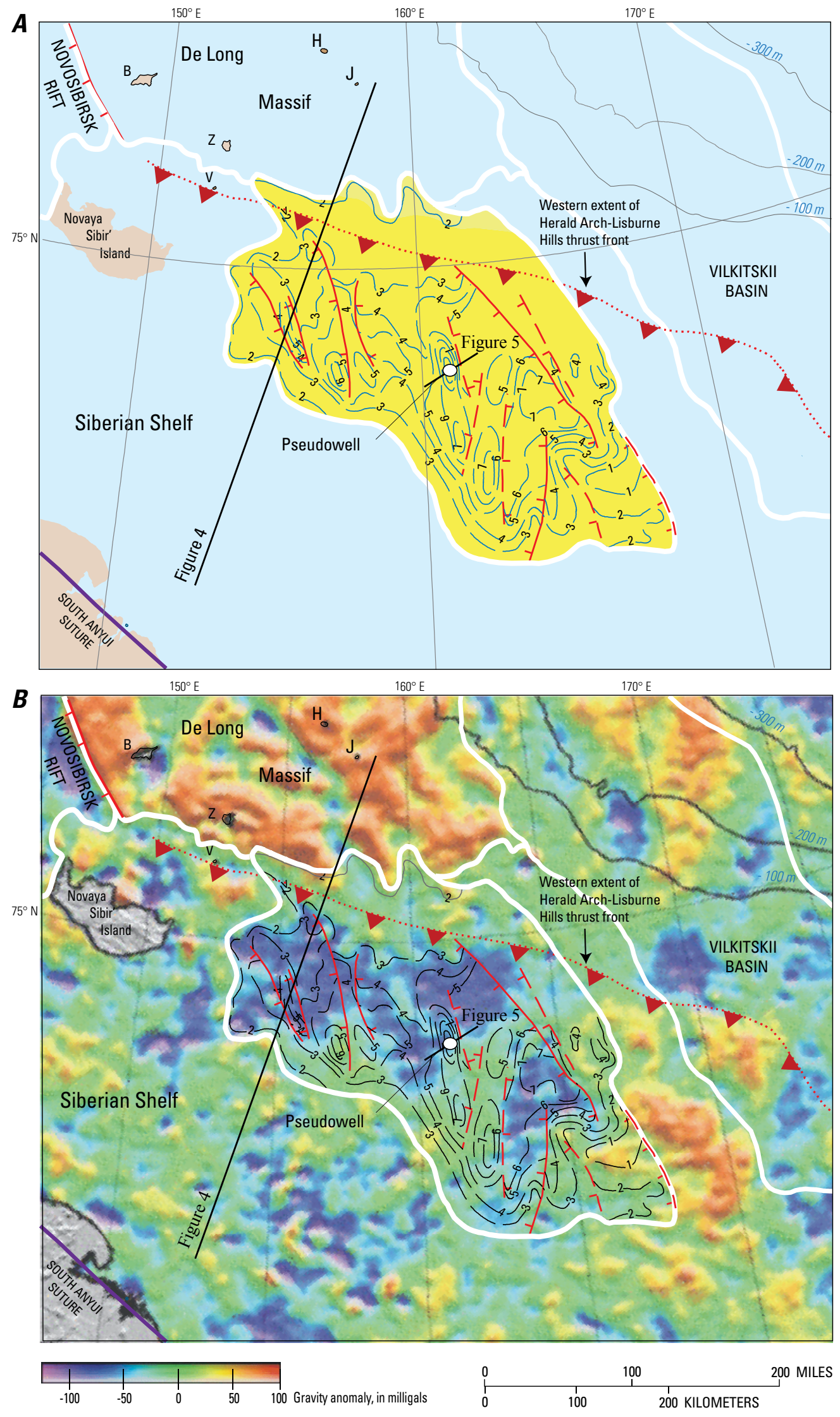

Figure 2. Selected details of the East Siberian Sea (adapted from Grantz and others, 2009). $A$, Map of East Siberian Sea Basin (yellow), showing depth to acoustic basement (in kilometers) and locations of selected seismic lines and pseudowell used in burial-history analysis. Islands in the De Long Massif area: $B$, Bennett; $H$, Henrietta; J, Jeannette; V, Vilkitskii; Z, Zokhov. $B$, Area of figure $2 A$, superimposed on a free-airgravity-anomaly map (adapted from Mazarovich and Sokolov, 2003). Note general agreement of acoustic-basement depth contours with negative gravity anomalies for much of the basin, but not in that part of the basin north of the Herald Arch-Lisburne Hills-Brooks Range thrust front, where a seismic-reflection profile (fig. 4) indicates a greater thickness north of the thrust front ( $>3$ seconds two-way traveltime) than that to the south-a relation opposite to that suggested by the gravity anomalies. 


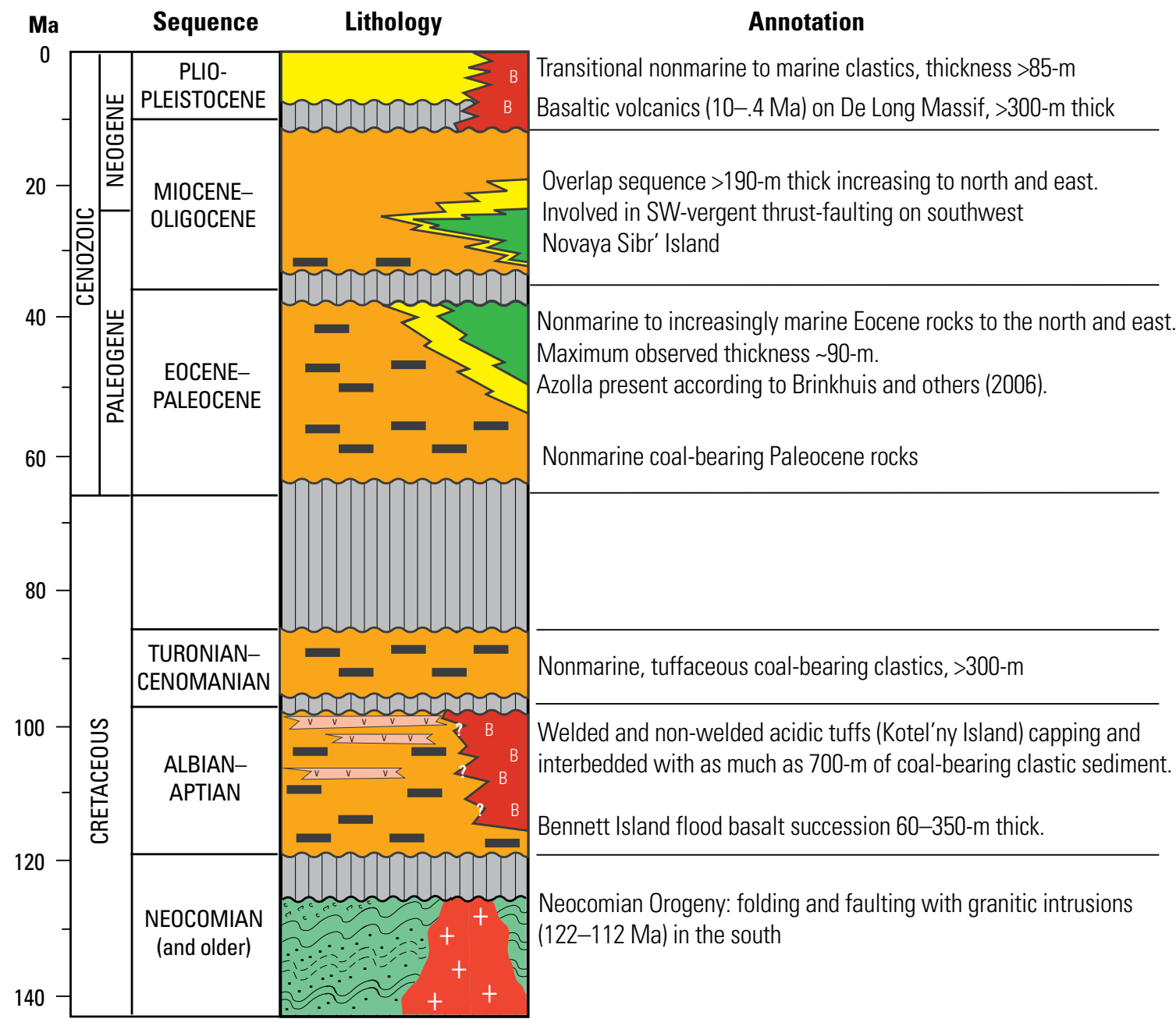

\section{EXPLANATION}

\begin{tabular}{|c|c|c|c|c|c|c|c|}
\hline 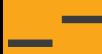 & Nonmarine coal-bearing rocks & & Marine rocks & $\begin{array}{ll}\text { B } & \text { B }\end{array}$ & Basaltic volcanic rocks & & Metasedimentary rocks \\
\hline & Nonmarine to marine rocks & $\begin{array}{lll}v \\
v & v & v \\
v & v\end{array}$ & Acidic volcanic rocks & & Hiatus & $+\quad+$ & Granitic rocks \\
\hline
\end{tabular}

Figure 3. Schematic stratigraphic succession that likely extends and thickens into the East Siberian Sea Basin, interpreted from outcrops and shallow drill holes on the New Siberian Islands (Kos'ko and Trufanov, 2002; Kuzmichev, 2009). 
showing regional structural relations (fig. 4). The map (fig. 2 ), with contours on acoustic basement, shows the basin to be mostly $>2 \mathrm{~km}$ deep and to have a maximum sedimentary thickness locally of $>8 \mathrm{~km}$. South of the thrust front, where most seismic sections are located (for example, Franke and others, 2004), the basin is characterized by elongate northerly trending sedimentary depocenters commonly bounded by syndepositional normal faults. Comparison of the basin outline, isopachs, and fault trends with free-air gravity anomalies (fig. $2 B$ ) shows moderately good agreement, except for that part of the basin north of the thrust front. In that area, although gravity anomalies suggest thinner strata than south of the thrust front (where more negative anomalies occur), the seismic profile (fig. 4) indicates the opposite relation: a greater thickness of strata north of the thrust front than to the south.

The stratigraphic section (fig. 3), as interpreted from outcrops and shallow boreholes reported from the New Siberian Islands, shows only that part of the succession believed to be present in the East Siberian Sea Basin. Rocks older than Early Cretaceous (Neocomian) in this region (Ordovician through Early Cretaceous [Valanginian]) have been affected to varying degrees by Late Jurassic through Early Cretaceous deformation related to the closure of the South Anyui Ocean. These older rocks consist of well lithified clastic and carbonate strata that are considered to form acoustic basement in the East Siberian Sea Basin (Kos'ko and Trufanov, 2002; Franke and others, 2004). The midCretaceous and younger sedimentary succession is unlithified and dominated by nonmarine clastic sedimentary rocks that are coal-bearing in the Cretaceous and Paleogene section. Paralic to shallow marine strata are reported in the Eocene, Oligocene, and Pliocene-Pleistocene sections. Rhyolitic volcanic rocks occur in the Albian section on Kotel'ny Island, and Albian and Neogene basalt is present on Bennett Island. Neogene basalt is present on Vilkitksii and Zokhov Islands on the De Long Massif (fig. 2).

The northeast-trending cross section (fig. 4), $>450 \mathrm{~km}$ long, is based on the only seismic profile (LARGE 89001) to cross the entire East Siberian Sea Basin. The section, which extends northward from the Siberian Sea shelf across the western part of the East Siberian Sea Basin onto the De Long Massif (fig. 2), is also the only published seismic profile in the basin to cross the westward extent of the Herald ArchLisburne Hills-Brooks Range thrust front, thus providing key information on the position and structure of this feature. A detailed view and interpretation of this feature by Drachev and others (2001, fig. 3) shows a northward-vergent, high-angle reverse fault that deforms the adjacent sequence, interpreted by them as Albian(?), producing fault-bounded antiforms interpreted as positive flower structures, thus leading to a conclusion of transpressional deformation. Overall, this regional section was interpreted by Drachev and others (2001) as consisting of at least six unconformity-bounded sequences, ranging in age from mid-Cretaceous to Holocene, that gradually thicken northward from $<1$-s two-way traveltime in the south to $\sim 3.5$-s two-way traveltime in fault-bounded deeps before shallowing to $<0.5$-s two-way traveltime at its north end on the De Long Massif. The section shows that the north and south boundaries of the East Siberian Sea Basin in this area occur where the reflective sedimentary section exceeds $\sim 1.5$-s two-way traveltime $(\sim 2 \mathrm{~km})$, rather than at any distinct geologic break. Although six sequences have been identified, in any one place along the section only three sequences are commonly present. Other seismic sections in the basin typically are interpreted as consisting of only three sequences, to which various ages have been assigned by different investigators on the basis of geology of the New Siberian Islands and regional tectonostratigraphic history. As summarized by Kos'ko and Trufanov (2002), the youngest sequence has been interpreted to be Pliocene and Pleistocene, late Miocene through Pleistocene, or Oligocene and younger; the middle sequence has been interpreted to be Paleocene through Miocene or Oligocene through mid-Miocene; and the oldest sequence has been interpreted as mid-Late Cretaceous or Paleocene and Eocene. In the view of Kos'ko and Trufanov (2002), who mapped the geology of the New Siberian Islands, the three sequences are (1) mid- to Late Cretaceous, (2) Paleocene through Miocene, and (3) Pliocene and Pleistocene.

\section{Petroleum Systems}

No petroleum systems have been identified in the East Siberian Sea Basin. Some indications of gas are evident on available seismic records but these are rare and poorly resolved. No hydrocarbon indications have been reported from the New Siberian Islands, although the lower part of the Triassic and Jurassic shallow-marine mudstone section on Kotel'ny Island was described as "notable for oil shales" (Kuzmichev, 2009). Likely petroleum-source rocks in the East Siberian Sea Basin are coal and carbonaceous shale of Cenozoic and possible mid-Cretaceous age. Shallow-marine mudstone of Eocene and Oligocene age may also be present, on the basis of observed facies trends on Novaya Sibir' Island. The presence of the early Eocene Azolla interval on the New Siberian Islands was indicated by Brinkhuis and others (2006). Although this interval is sufficiently rich in organic matter to be considered a potential source rock on the Lomonosov Ridge $-2,000 \mathrm{~km}$ to the north, near the North Pole-its character in the East Siberian Sea Basin area is unknown. Of even greater uncertainty is the presence of Paleozoic and Mesozoic source rocks within acoustic basement-not only are their original thickness, distribution, organic richness, and thermal maturity unknown, but they also have been affected by the Neocomian orogeny. For these reasons, the most likely petroleum-source rocks in the East Siberian Sea Basin are considered to be gas prone.

Burial history of a pseudowell located in the deepestknown part of the basin on the seismic line in figure 5 was modeled to determine the thermal maturity and timing of petroleum generation (fig. 6). This analysis, using a constant 
heat flow of 50 milliwatts per square meter (determined from analysis of the Popcorn well on the Chukchi Shelf) and the sequence ages interpreted by Franke and others (2004), suggests that onset of petroleum generation would occur at $\sim 3.8 \mathrm{~km}$ of burial as early as middle Eocene ( $\sim 47 \mathrm{Ma})$ for source rocks at the base of the lowermost sequence. In such depocenters like the one modeled, postulated source rocks as young as Oligocene would lie within the oil window at maximum burial, but outside of such depocenters, only source rocks older than Eocene are likely to be within the oil window. By using the 4-km contour on acoustic basement shown in figure 2 as a proxy for the top of the oil window, one can estimate that about half of the East Siberian Sea Basin would have enough sedimentary thickness sufficient to occur within the oil window. The area north of the Herald Arch-Lisburne Hills-Brooks Range thrust front (fig. 2) that may comprise the foreland basin succession could have a source potential in marine Cretaceous rocks if the interpreted geometry and age determinations shown in figure 4 are correct, and if those characteristics pertain to the entire thrust front across the basin.

\section{East Siberian Sea Basin Assessment Unit}

AU Description.-The East Siberian Sea Basin assessment unit encompasses the entire basin, about 120,000 $\mathrm{km}^{2}$ (fig. 2). The basin is mostly a post-orogenic successor basin of uncertain origin, although the northern part may include part of the Cretaceous foreland-basin system of the underlying orogenic belt. Basin fill, locally $>8 \mathrm{~km}$ thick, typically consists of three unconformity-bounded sequences, the ages of which are uncertain because of the absence of well penetrations. Although regional tectonic considerations, in combination with geologic studies on nearby islands, have resulted in different age assignments for these sequences by different investigators, all of them agree that the sequences are mostly Cenozoic, but some interpretations include midCretaceous and Upper Cretaceous strata. On the basis of the geology of nearby islands, the sequences are inferred to be composed predominantly of coal-bearing, nonmarine clastic sedimentary rocks with probable shallow-marine intervals in parts of the Eocene, Oligocene, and Pliocene-Pleistocene section. Volcanic rocks are known in the late Early Cretaceous and Pliocene-Pleistocene parts of the exposed succession.

Seismic-reflection profiles show that structures are common in the basin but limited to the two older sequences. The youngest sequence, generally $\sim 1 \mathrm{~km}$ thick, forms an undisturbed cap. Typically, structures consist of north-trending listric normal faults associated with grabens, sags, and faulted anticlines. Stratal thickening in sags and grabens indicates that they were formed mostly during deposition of the middle sequence (Paleocene through Miocene; Paleocene and Eocene; or Oligocene and Miocene). Change in stratal thickness across some faults suggests a component of transtensional deformation.
Petroleum source rocks are postulated to be coal, carbonaceous shale, and shallow-marine mudstone and so are expected to be predominantly gas prone. Gas indications (velocity sags and reflector "fadeouts") have been observed on some seismic records but are rare and poorly resolved. The Eocene Azolla interval likely is present (Brinkhuis and others, 2006, table S-1), but its organic-carbon richness, areal extent, and burial depth in the East Siberian Sea Basin are unknown. Source rocks of Paleozoic and Mesozoic age also may be present in acoustic basement; however, their thickness, distribution, or source characteristics are unknown. On the basis of burial-history analysis, only that part of the basin with $>\sim 3.8$ $\mathrm{km}$ of fill is estimated to be capable of petroleum generation.

Geological Analysis of Assessment Unit Probability.Considering data limitations and sparse exploration activity, the probability that the East Siberian Sea Basin AU contains at least one undiscovered accumulation $>50$ million barrels of oil equivalent (MMBOE) is considered to be about 22 percent (table 1).

Charge.-A probability of 0.4 was assigned to charge sufficiency in this assessment unit. Petroleum-source rocks were considered to be coal and carbonaceous and shallowmarine mudstone of unknown quality and thickness.

Furthermore, the area in which these rocks are mature is limited to that part of the basin where they are buried to depths $>3.8 \mathrm{~km}$, so that for most of the basin, only source rocks Eocene and older would be mature. Cretaceous marine source rocks may be present in the part of the basin north of the westward extension of the Herald Arch-Lisburne Hills-Brooks Range thrust front. Source rocks of unknown quality and distribution within acoustic basement may also be present.

Rocks.-A probability of 0.8 was assigned to the adequacy of reservoirs, traps, and seals in this assessment unit. Sandstone reservoirs may be present throughout the section and only limited by depth-related diagenetic effects. Unconformity and fault-trap geometries are abundant on available seismic images, where folded and faulted strata of the two older sequences are truncated and, possibly, sealed by the youngest sequence. Inadequate mudstone and fault seals are considered to be a significant risk.

Timing and Preservation.-Within the basin, currently at maximum burial and with a history of continuous subsidence, a favorable probability of 0.7 was assigned to the adequacy of timing and preservation of petroleum accumulations greater than the minimum size within this assessment unit.

Analogs.-A search of the U.S. Geological Survey (USGS) World Analog Database (Charpentier and others, 2008) on coaly source rock, Type III kerogen, yielded 24 analog assessment units that were then pared down by eliminating analogs with marine-deltaic settings and foreland basins with fold-and-thrust structures.

Number of Petroleum Accumulations. - On the basis of the set of analogs, the total petroleum accumulations $>50$ MMBOE was set to 1, 5, and 40 for the minimum, median, and maximum, respectively. 
Table 1. Assessment results for the East Siberian Sea Basin Province (conventional undiscovered resources).

[AU, assessment unit; BCF; billion cubic feet; MMB, million barrels; MMBOE, million barrels of oil equivalent. Results shown are fully risked estimates. For gas fields, all liquids are included under the natural gas liquids category. F95, 95-percent probability of at least the amount tabulated, and so on for F50 and F5. Fractiles are additive under the assumption of perfect positive ocrrelation. N/A, not applicable]

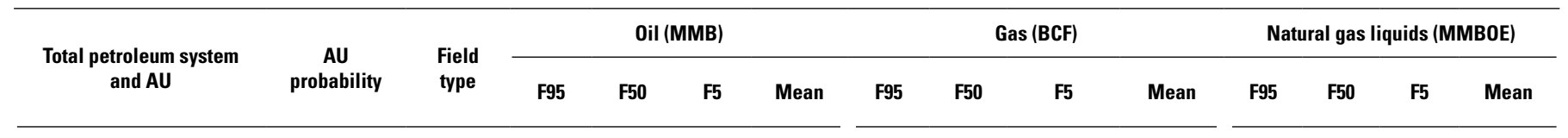

East Siberian Sea Basin Province-Mesozoic-Cenozoic composite total petroleum system

\begin{tabular}{|c|c|c|c|c|c|c|c|c|c|c|c|c|c|c|}
\hline $\begin{array}{l}\text { East Siberian Sea Basin } \\
\qquad \mathrm{AU}\end{array}$ & .0224 & Oil & 0 & 0 & 118 & 20 & 0 & 0 & 246 & 39 & 0 & 0 & 4 & 1 \\
\hline
\end{tabular}

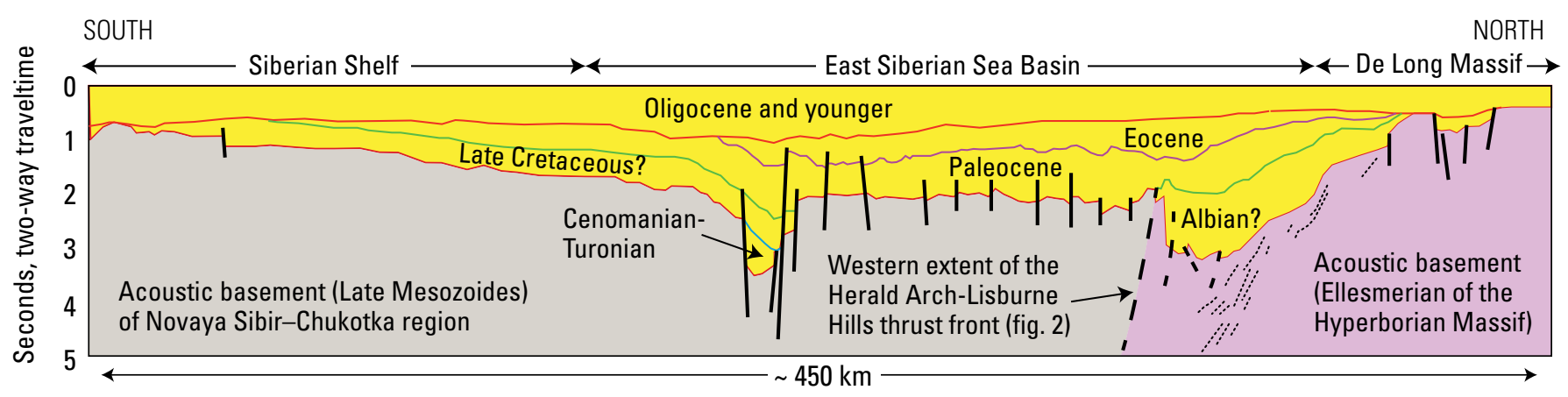

Figure 4. Cross section drawn from analysis of seismic line LARGE 89001, showing depositional sequences and provisional ages interpreted by Drachev and others (2001). Location of the line is shown in figure 2, and subdivisions (shelf, basin, massif) are from the map by Grantz and others (2009). Oligocene and younger interval unconformably overlies entire basin, thus providing a likely seal for hydrocarbon traps. Albian? interval is interpreted as part of a foreland basin, deformed near the thrust front with northward onlap thinning on the De Long Massif. Dotted lines in acoustic basement are reflective seismic horizons.

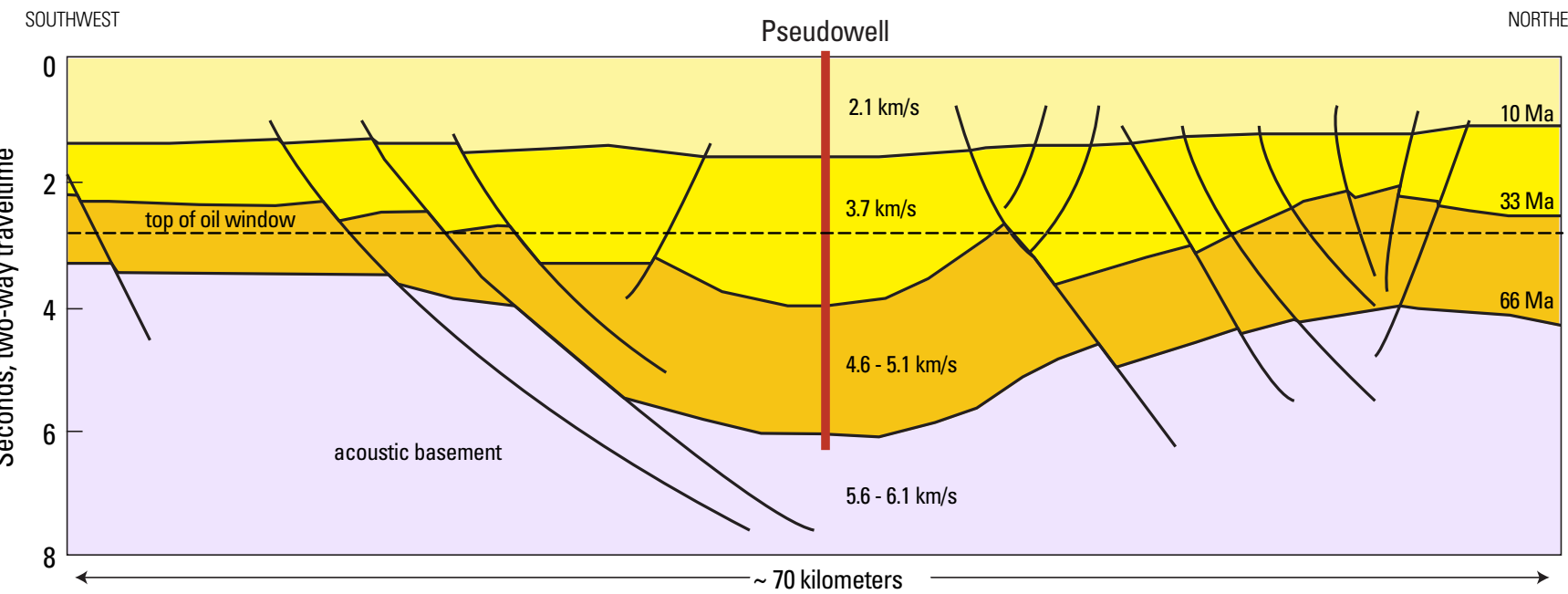

Figure 5. Cross section of deep synclinal sag and associated listric normal faults in the East Siberian Sea Basin drawn from analysis of seismic profile BGR94-12 (Franke and others, 2004, fig. 9). Threefold stratigraphic subdivision of the basin fill, stacking velocities, inferred ages of bounding unconformities, and characteristic extensional (transtensional?) faulting follows interpretation by Franke and others (2004). The pseudowell shows the location of burial-history analysis (fig. 6) and estimated top of the oil window at a depth of $\sim 3.8 \mathrm{~km}$ (2.7-s two-way traveltime). See figure 2 for location. 

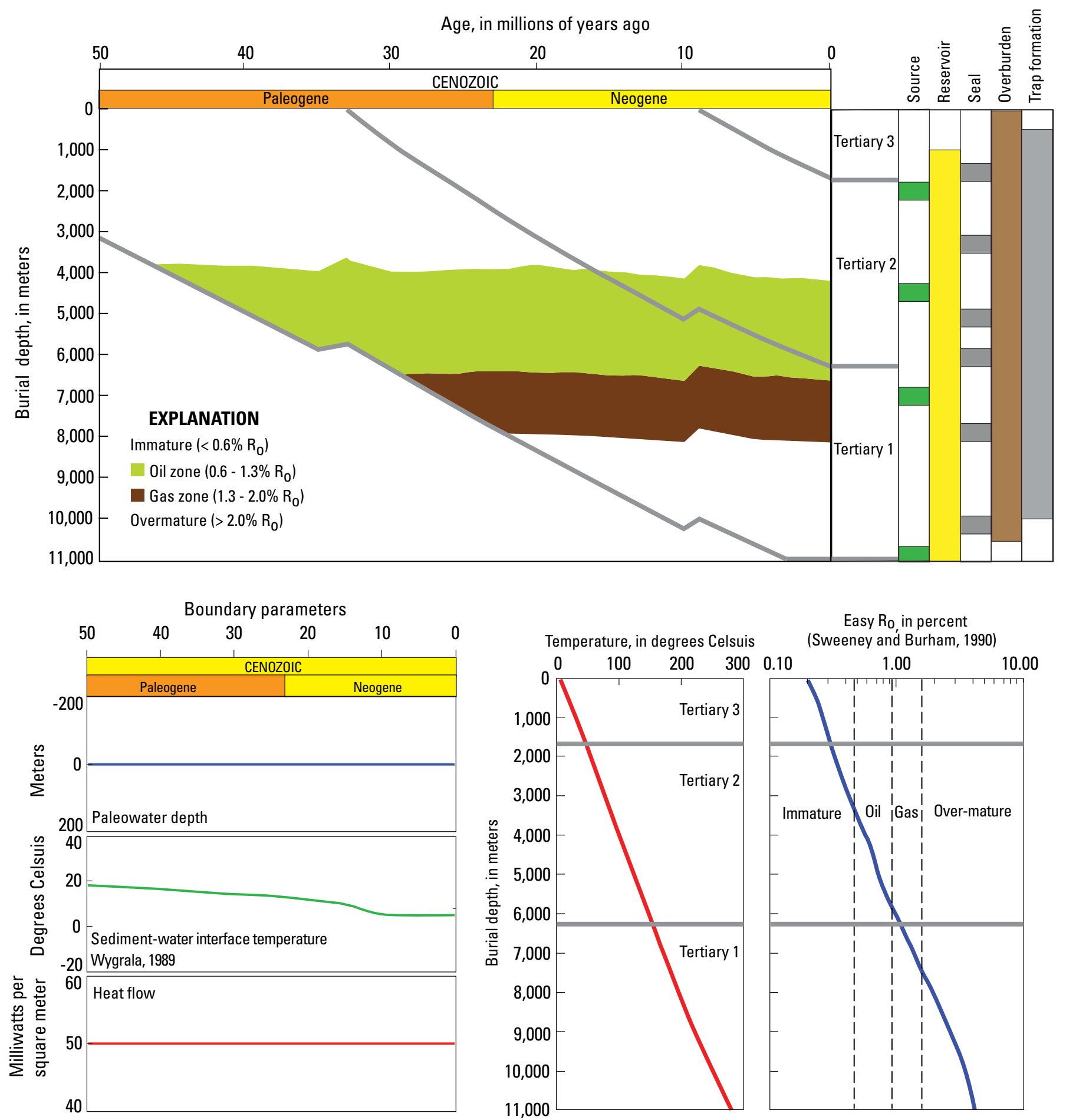

Figure 6. Burial-history analysis of pseudowell located in a deep synclinal sag of the East Siberian Sea Basin traversed by the seismic-reflection profile in figure 5. Sequences, ages, and depths follow details provided by Franke and others (2004) and are summarized in figure 5. Occurrence of "source," "reservoir," and "seal" components of the petroleum system are hypothetical. Sediment-water-interface temperatures from Wygrala (1989). Ro, vitrinite reflectance, in percent (\%). 
Oil/Gas Mix.-On the basis of the inferred dominance of gas-prone kerogen in coaly source rocks and the absence of oil-prone source-rock indications, the minimum, median, and maximum ratios for oil/gas mix were set at $0,0.02$, and 0.1 , respectively. With an oil/gas mix in this range, the resulting numbers of undiscovered gas fields are 1,2, and 18, and of undiscovered oil fields 0,0 , and 2.

Accumulation Size Distribution.-The median and maximum oil accumulation size was set at 70 and 300 million barrels of oil, respectively; and the median and maximum gas accumulation size was set at 500 and 5,000 billion cubic feet of gas (BCFG), respectively. The minimum field size required for a quantitative assessment as part of the Circum-Arctic Resource Appraisal was set at 50 MMBOE.

Estimated Maximum Field Size.-Maximum accumulation sizes of 50-100 MMBO and 1-2 trillion cubic feet of gas were selected on the basis of the interpretation that some very large traps may be present but that the maximum accumulation size would be constrained by limited hydrocarbon charge and, possibly, by seal integrity.

Ancillary properties and coproduct ratios relied on world averages reported by Charpentier and others (2008).

\section{Summary of Province Assessment Results}

Probabilistic estimates of the volumes of undiscovered, technically recoverable hydrocarbons for the East Siberian Sea Basin are summarized in table 1, including mean estimates of $\sim 20 \mathrm{MMBO}$ and $579 \mathrm{BCFG}$, nonassociated.

\section{Acknowledgments}

We thank Timothy R. Klett and Thomas E. Moore of the U.S. Geological Survey for their reviews of the manuscript. The U.S. Department of Energy funded the purchase of selected seismic data in the basin.

\section{References Cited}

Brinkhuis, H., Schouten, S., Collinson, M.E., Sluijs, A., Sinninghe-Damste, J.S., Dickens, G.R., Huber, M., Cronin, T.M., Onodero, J., Takahashi, K., Bujak, J.P., Stein, R., van der Burgh, J., Matthiessen, J., Eldrett, J.S., Harding, I.C., Lotter, A.F., Sangiorgil, F., de Leeuw, J.W., Backman, J., Moran, K., and expedition scientists, 2006, Episodic fresh surface waters in the Eocene Arctic Ocean: Nature, v. 441, no. 1, p. 606-609, doi:10.1038/nature04692.
Charpentier, R.R., Klett, T.R., and Attanasi, E.D., 2008, Database for assessment unit-scale analogs, exclusive of the United States: U.S. Geological Survey Open-File Report 2007-1404, 61 p. [Also available at http://pubs.usgs.gov/ of/2007/1404/.]

Drachev, S.S., Elistratov, A.V., and Savostin, L.A., 2001, Structure and seismostratigraphy of the east Siberian Sea shelf along the Indigirka Bay-Jannetta Island seismic profile: Doklady Earth Sciences, v. 337A, no. 3, p. 293-297.

Filatova, N.I., and Khain, V.E., 2007, Tectonics of the eastern arctic region: Geotectonics, v. 41, no. 3, p. 171-194.

Franke, D., Hinz, K., and Reichert, C., 2004, Geology of the East Siberian Sea, Russian arctic, from seismic imagesStructures, evolution, and implications for the evolution of the Arctic Ocean Basin: Journal of Geophysical Research, v. 109, p. B07106, doi:07110.01029/02003JB002687.

Grantz, A., Scott, R., Drachev, S.S., and Moore, T.E., 2009, Tectonostratigraphic accumulations of the Arctic Region, $65^{\circ}-90^{\circ} \mathrm{N}$, that may be prospective for hydrocarbons: American Association of Petroleum Geologists GIS-UDRIL Open-File Library, 68 p., 4 sheets, scale 1:4,000,000.

Kos'ko, M.K., and Trufanov, G.V., 2002, Middle Cretaceous to Eopleistocene sequences on the New Siberian IslandsAn approach to interpret offshore seismic: Marine and Petroleum Geology, v. 19, p. 901-919.

Kuzmichev, A.B., 2009, Where does the South Anyui suture go in the New Siberian Islands and Laptev Sea? Implications for the Amerasia Basin origin: Tectonophysics, v. 463 , p. $86-108$.

Mazarovich, A.O., and Sokolov, S.Y., 2003, Tectonic subdivision of the Chukchi and East Siberian Seas: Russian Journal of Earth Sciences, v. 5, no. 3, p. 185-202.

Wygrala, B.P., 1989, Integrated study of an oil field in the southern Po Basin, northern Italy: Berichte der Kernforschungsanlage Julich, no. 2313, ISSN 0366-0885, 217 p. 


\section{Appendix. Input Data for the East Siberian Sea Basin Assessment Unit}

Appendix is available online only, and may be accessed at https://doi.org/10.3133/pp1824Y

Menlo Park Publishing Service Center, California

Manuscript approved for publication May 15, 2017

Edited by George Havach and Claire Landowski

Layout and design by Geraldine Dang 


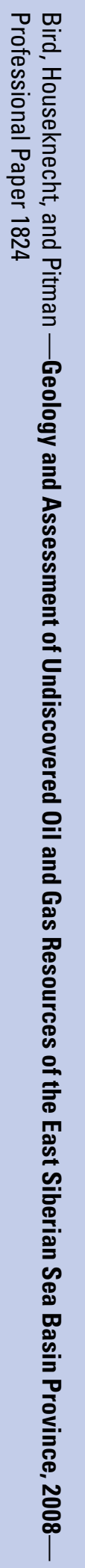

